\title{
Z działalności Koła Naukowego Studentów Filozofii Uniwersytetu Papieskiego Jana Pawła II w Krakowie
}

W roku 2012/2013 działalność koła filozoficznego, oprócz stałych punktów „programu” w postaci ogólnopolskich konferencji, charakteryzowała się dużą liczbą kameralnych spotkań dyskusyjnych oraz szeroko zakrojoną aktywnością organizatorską.

Członkowie Sekcji Filozofii Teoretycznej zorganizowali kilkanaście spotkań pod hasłem „Dowody na istnienie Boga". Cykl dyskusji na ten temat rozpoczął się 4 marca 2013 roku i był kontynuowany późnymi popołudniami w wybrane poniedziałki. W dyskusjach brało udział, w zależności od dnia i pory roku, od trzech do dziesięciu osób, w tym studenci, doktoranci i absolwenci krakowskich uczelni: UPJPII, UJ, AGH. Spotkania nawiedzał gościnnie $\mathrm{dr}$ Jakub Gomułka (Katedra Filozofii Boga UPJPII). W ramach cyklu udało się porozmawiać na następujące tematy: „Dlaczego prawie na pewno nie ma Boga?”; ,Jak spraw- dzić, że Bóg istnieje?”; „Czy jest sens pytać o istnienie Boga?”; „Czy można dowieść nieistnienia Boga?”; „Jak przekonać ateistę?”. Czytaliśmy teksty bardzo rozmaitych autorów, poczynając od słynnych propagatorów ateizmu, takich jak Richard Dawkins czy Jan Hartman, poprzez (niemal) równie znanych teistów - tu można wymienić przede wszystkim Johna Hicka. Nie zabrakło także autorów, których trudno jednoznacznie postawić po jednej ze stron barykady, np. „nawróconego” na deizm Anthony'ego Flewa czy Johna N. Findlay'a. Co istotne, specyfika spotkań organizowanych przez nasze koło nie polegała na beznamiętnej lekturze tekstów czy odtwarzaniu argumentów poszczególnych autorów. Stanowiły one zawsze dobry punkt wyjścia dla szerzej zakrojonych dyskusji. Ich zwieńczeniem okazała się kwestia (nie)konkluzywności dowodów na istnienie Boga. 
Najwięcej emocji wzbudzały tradycyjnie fragmenty Boga urojonego Richarda Dawkinsa - przede wszystkim te, które dotyczą jego krytyki dowodów na istnienie Boga. Na spotkaniach dyskutowano m.in. o dowodzie ontologicznym: obie jego wersje z II i III rozdziału Proslogionu porównywano $\mathrm{z}$ dowodem Kartezjusza (z Medytacji o pierwszej filozofii, trzeciej i piątej). Spierano się, na ile teksty te można ze sobą zestawiać, ze względu na skrajnie różny kontekst (tradycje scholastyczne versus racjonalność nowożytna) oraz punkt wyjścia (modlitwa versus sceptycyzm). W tym punkcie nie udało się dojść do porozumienia. Długa i burzliwa dyskusja toczyła się wokół pięciu dróg św. Tomasza z Akwinu oraz ich krytyki. Dowód kosmologiczny został przez jednych jednoznacznie odrzucony ze względu na możliwość regresu w nieskończoność, inni zaś bronili jego aktualności. Zastanawiano się, czy można o istnieniu Boga rozstrzygać eksperymentalnie i czy dla niektórych dróg mają znaczenie osiągnięcia współczesnej fizyki. Ostatecznie jednak większość dyskutantów zgodziła się, że analiza Tomaszowych dróg powinna się toczyć przede wszystkim na gruncie metafizycznym, a nie naukowym (nie zaprzeczając niewątpliwym zależnościom, jakie zachodzą pomiędzy tymi dziedzinami). Zestawiliśmy również tak zwaną piątą drogę z argumentem Inteligentnego Projektu. W tym zakresie zwracaliśmy uwagę na różnicę między wydarzeniami losowymi i pseudolosowymi (zdarzenia pseudolosowe w pierwotnym sensie posiadają autora, co wiąże się z teorią ewolucji oraz hipotezą istnienia potencjalnego Stwórcy). Pytaliśmy, jaki jest stosunek Boga do praw logiki, w tym przede wszystkim o zasadę niesprzeczności, a także o jego stosunek do praw przyrody. Czy wszechmocny Bóg może je zmieniać? A może musi im podlegać? Jeden $z$ dyskutowanych tematów dotyczył utożsamiania istoty najwyżej, najdoskonalszej czy najpotężniejszej, z religijnie rozumianym Bogiem. Konsensus w tej mierze polegał na uznaniu, że takie utożsamienie jest nieuprawnione. $\mathrm{Na}$ niektórych spotkaniach podnoszona była także kwestia doświadczenia religijnego. Niektórzy bronili tezy, że ludzie mają różne odczucia, a nawet halucynacje i urojenia, i jest 
to ich osobista sprawa, która nie może stanowić argumentu w racjonalnej dyskusji.

W ramach działalności Sekcji Filozofii Starożytnej odbyły się trzy spotkania, dotyczące recepcji starożytnych autorów (głównie Platona) przez współczesnych badaczy, szczególnie za szkoły tybińskiej (Hans Krämer, Thomas A. Szlezák, Giovanni Reale). Spotkania koncentrowały się wokół Platońskiej filozofii języka, semiotyki i ontologii - zwłaszcza w świetle treści tzw. nauk niepisanych. Członkowie Sekcji podjęli także trud lektury tekstów w językach źródłowych. Czytano ponadto takich autorów, jak: Gregory Vlastos (A Metaphysical Paradox), HansGeorg Gadamer (Idea dobra w dyskusji między Platonem i Arystotelesem) czy Bogdan Dembiński (Późny Platon i Stara Akademia).

Sekcji Filozofii Przyrody spotkała się dwukrotnie. W semestrze zimowym roku 2012/2013 temat spotkania brzmiał: „Radykalny pragmatyzm a klasyczna koncepcja prawdy", w semestrze letnim zaś: „Paradoksy w mechanice kwantowej".

Sekcja Estetyki kontynuowała formy działalności z ubiegłych lat, takie jak: wspólne wyjścia do teatru i kina, udział w wernisażach oraz kameralne dyskusje w krakowskich kawiarenkach.

Do ważnych wydarzeń minionego sezonu należy zaliczyć powstanie pod koniec listopada 2012 nowej Sekcji Metafizyki, której opiekunem został ks. prof. dr hab. Stanisław Wszołek. Co istotne, Sekcja powstała z inicjatywy studentów drugiego roku filozofii (studiów licencjackich). Dotychczas miały miejsce dwa spotkania: „Oczywistość w naukach metafizycznych" (w spotkaniu uczestniczyli ks. prof. dr hab. Stanisław Wszołek oraz ks. dr hab. Adam Olszewski) oraz „Tożsamość nie jest ważna" (dyskutowano w oparciu o tekst Dereka Parfita). Frekwencja oscylowała wokół dziesięciu osób.

Oprócz spotkań o charakterze dyskusyjnym, w poszczególnych sekcjach członkowie Koła udzielali się także w inny sposób, przede wszystkim biorąc czynny udział w organizacji dwóch konferencji. Za największy sukces należy uznać piątą edycję ogólnopolskiej konferencji z cyklu „Wokół myśli Michała Hellera", której temat w roku 2012 brzmiał: „Studium 


\section{Sprawozdania}

przypadku". W obradach wzięli udział m.in.: ks. prof. dr hab. Michał Heller, prof. dr hab. Wojciech Sady, a także prof. dr hab. Tomasz Placek. Na wiosnę zorganizowano natomiast drugą edycję Ogólnopolskiej Konferencji Doktorantów: „(Nie)konkluzywność dowodów na istnienie Boga", który (całkiem nieprzypadkowo) korespondował z tematami spotkań Sekcji Filozofii Teoretycznej. Członkowie Koła zorganizowali także panel dyskusyjny o kontrowersyjnie brzmiącym tytule: „Koniec filozofii?”. Dyskusja, w której wzięli udział goście: dr Jakub Gomułka, dr Mateusz Hohol i dr Łukasz Kołoczek, stanowiła symboliczne zamknięcie prac Koła w roku akademickim 2012/2013.

Dorota Bentke Zofia Sajdek Mikołaj Małecki 